\title{
Tingkat Patinasi Dan Pembundaran Artefak Litik Sebagai Petunjuk Posisi Stratigrafis Dan Lokasi Asal Pengendapan, Kajian Artefak Lembah Sungai Baksoka
}

\section{Muhammad Hidayat}

Keywords: data transformation, context, use wear, deposition, stone tools, lithics, river

\section{How to Cite:}

Hidayat, M. (2001). Tingkat Patinasi Dan Pembundaran Artefak Litik Sebagai Petunjuk Posisi Stratigrafis Dan Lokasi Asal Pengendapan, Kajian Artefak Lembah
Sungai
Baksoka.
Berkala
Arkeologi,
21(2),
$1-8$.

https://doi.org/10.30883/jba.v21i2.837

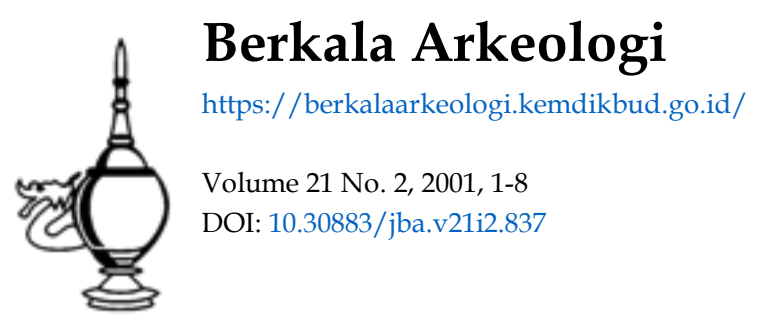




\title{
TINGKAT PATINASI DAN PEMBUNDARAN ARTEFAK LITIK SEBAGAI PETUNJUK POSISI STRATIGRAFIS DAN LOKASI ASAL PENGENDAPAN, KAJIAN ARTEFAK LEMBAH SUNGAI BAKSOKA
}

\author{
Muhammad Hidayat \\ (Balai Arkeologi Yogyakarta)
}

\section{Pendahuluan}

Sungai pada umumnya mengalir pada lokasi yang paling rendah di lingkungannya, sehingga merupakan tujuan aliran pengendapan materi yang berasal dari tempat yang lebih tinggi. Oleh karenanya materi endapan sungai merupakan materi yang heterogen, bisa berasal dari dalam satu horison maupun berbeda, bisa berasal dari lokasi yang sama maupun berbeda. Demikian pula terhadap sekumpulan artefak, khususnya alat litik yang terdapat di dasar sungai. Sekumpulan alat litik yang terdapat di dasar sungai bisa berasal dari lokasi yang satu horison maupun berbeda, bisa berasal dari lokasi yang berjarak sama maupun berbeda. Untuk mengetahui masingmasing asal, yaitu posisi vertikal (posisi stratigrafi) maupun horisontal (jarak) alat litik yang terendapkan di dasar sungai ini dapat dilakukan dengan menganalisis tingkat patinasi dan pembundaran.

Patinasi pada alat litik merupakan lapisan yang biasanya berwarna coklat atau coklat kemerahan yang melekat pada permukaan artefak tersebut. Keberadaan patinasi pada alat litik ini diakibatkan oleh materi di lingkungan pengendapan. Semakin tinggi tingkat patinasi pada alat litik menyiratkan semakin tua usia artefak tersebut, demikian pula sebaliknya. Selain perbedaan jangka masa pengendapan, perbedaan materi lingkungan pengendapan dapat mempengaruhi tingkat patinasi pada masing-masing alat litik. Oleh karena itu dalam penerapan analisis perbedaan tingkat patinasi pada alat litik, lebih tepat hanya digunakan pada sekumpulan artefak yang terendap pada lingkungan yang sama.

Pembundaran pada alat litik disebabkan oleh gesekan pada permukaan, terutama pada bagian tajaman alat tersebut ketika tertransportasi oleh aliran air. Semakin tinggi intensitas gesekan maka akan semakin membundar alat litik tersebut. Hal ini memberikan arti bahwa semakin lanjut tingkat pembundaran pada alat litik yang ditemukan pada lokasi pengendapan terakhirnya maka semakin jauh lokasi asal/pengendapan awal artefak tersebut.

Penerapan analisis tingkat patinasi dan pembundaran secara kualitatif yang ditujukan untuk mendapatkan gambaran lokasi asal/pengendapan awal artefak telah dilakukan terhadap sekumpulan alat litik yang ditemukan di lembah Sungai Baksoka, yaitu pada 
teras-teras sungai tersebut. Khususnya analisis tingkat patinasi dalam penelitian ini digunakan untuk mengetahui posisi artefak pada teras, yang akhirnya untuk memperkirakan kronologi artefak. Berikut hasil dari penerapan analisis tersebut.

\section{Lembah Sungai Baksoka, Budaya dan Permasalahannya}

Sungai Baksoka merupakan salah satu sungai kuna yang berada di Kawasan Pegunungan Selatan Jawa. Aliran sungai ini diantaranya melintasi wilayah Kecamatan Pringkuku dan Punung, Pacitan. Beberapa bagian lahan di lingkungan aliran sungai telah diolah untuk dijadikan sebagai lahan pertanian dan perkebunan oleh masyarakat setempat.Namun di beberapa lokasi di lingkungan aliran sungai masih tampak singkapan dan materi sisa-sisa teras sungai berupa kerakal - bongkah batuan, baik yang masih terikat pada matriksnya maupun yang telah terlepas.

Di sepanjang lembah Sungai Baksoka tersebut banyak ditemukan sebaran alat-alat litik dari tradisi neolitik dan paleolitik. Alat-alat litik ini berada di permukaan tanah yang bercampur dengan materi teras maupun di dasar sungai yang bercampur dengan materi endapan lainnya seperti kerakal dan bongkah batuan maupun fosil kayu. Kondisi alat terutama yang menyangkut keutuhan, tingkat patinasi, maupun tingkat pembundaran adalah beragam.

Khususnya terhadap alat-alat paleolitik dari lembah Sungai Baksoka terkenal dengan sebutan Budaya Pacitanian. Kebanyakan alat-alat paleolitik dari lokasi ini berupa kapak perimbas, kapak penetak, serpih, bilah, dan serut. Namun sebagian besar alat yang sering ditemukan berupa kapak perimbas yang dibuat dari serpihan batu yang berukuran cukup besar dan tebal yang sengaja telah disiapkan. Pada umumnya bahan alat adalah tufa kersikan, dan sebagian kecil dibuat dari bahan gamping kersikan, rijang, dan kalsedon.

Sejak ditemukan pertama kali pada tahun 1934 oleh GHR van Koenigswald, penelitian terhadap Budaya Pacitanian telah dilakukan berulang kali diantaranya oleh Teilhard de Chardin, Hallam L. Movius Jr., de Terra, van Heekeren, G.J. Bartstra, dan Sartono (Hidayat, et.al., 2000). Sebagian besar artefak litik yang ditemukan oleh para peneliti tersebut berada di dasar sungai yang merupakan lokasi pengendapan terakhirnya. Oleh karena itu sebenarnya posisi stratigrafi/pengendapan awal alat-alat paleolitik yang banyak ditemukan pada dasar sungai tersebut belum banyak diketahui.

Terhadap posisi stratigrafi artefak yaitu posisi asal/awal pengendapan, beberapa peneliti telah memberikan pernyataan. Namun pernyataan yang diberikan belum ada kesepakatan, diantaranya mengenai jumlah teras, dan teras mana saja yang 
mengandung artefak. Bahkan terdapat pula informasi hasil pengamatan mengenai posisi stratigrafi artefak yang tampak kurang meyakinkan.

Menurut Chardin, di lembah Sungai Baksoka terdapat 3 teras yang semuanya mengandung alat serpih. Namun menurut de Terra hanya terdapat 2 teras di sekitar sungai tersebut, sedang Movius sependapat dengan Chardin bahwa di lokasi ini terdapat 3 teras. Hasil penelitian van Heekeren menunjukkan bahwa di lembah Sungai Baksoka terdapat 6 teras. Pada ketiga teras yang terendah terdapat artefak. Sementara itu hasil penelitian Bartstra menunjukkan bahwa hanya ada 4 teras di lembah Sungai Baksoka. Selain itu, penelitian terhadap teras Sungai Baksoka juga dilakukan oleh Sartono dkk. Hasil penelitiannya menunjukkan bahwa di lembah Sungai Baksoka tersebut terdapat 6 teras. Teras 1 (T1) yang merupakan teras tertinggi berada $134 \mathrm{~m}$ di atas permukaan aliran sungai sekarang, sedang teras 6 (T6) dengan ketinggian $0 \mathrm{~m}-4$ $m$ merupakan teras resen. Pada masing-masing teras sungai tersebut (teras 1 - 5), semuanya mengandung artefak (Sartono, dkk., 1978).

Pada tahun 2000 dan 2001, Balai Arkeologi Yogyakarta mengadakan penelitian terhadap sisa-sisa teras yang berada di Utara aliran Sungai Baksoka di wilayah Dusun Janglot, Desa Pelem, Kecamatan Pringkuku. Penelitian yang dilakukan lewat penggalian dengan pembuatan TP (test pit) dan pengamatan pada titik tertentu yang merupakan singkapan teras dan disebut dengan SP (Stasiun Pengamatan) ini menghasilkan informasi bahwa dilokasi tersebut terdapat 4 teras. Teras 1 berada pada ketinggian $17 \mathrm{~m}$ dari dasar sungai, teras 2 berada pada ketinggian $14 \mathrm{M}$, teras 3 berada pada ketinggian $6 \mathrm{M}$, dan teras 4 berada pada ketinggian $2 \mathrm{~m}$ dari dasar Sungai Baksoka. Pada masing-masing teras ini mengandung alat litik.

\section{a. Teras 1}

Pada teras 1 yang diwakili oleh lokasi SP1 ditemukan 4 alat paleolitik yang terdiri dari 2 kapak perimbas, sebuah serpih, dan sebuah serut. Kesemua alat litik ini dari bahan tufa kersikan. Adapun kondisi artefak yang meliputi tingkat patinasi dan pembundaran seperti dalam tabel 1 berikut.

Tabel 1.

\begin{tabular}{|l|c|c|c|c|}
\hline \multicolumn{1}{|c|}{ Kondisi } & Tingkat awal & Tingkat sedang & Tingkat lanjut & Jumlah \\
\hline Patinasi & - & - & 4 & 4 \\
\hline Pembundaran & 1 & 2 & 1 & 4 \\
\hline
\end{tabular}

\section{b. Teras 2}

Pada lokasi teras 2 yang diwakili oleh TP1 telah ditemukan 12 alat paleolitik yang terdiri dari 5 kapak perimbas, 2 kapak penetak, dan 5 serpih. Sepuluh alat di antaranya dibuat dari bahan tufa kersikan, sebuah dari bahan tufa gampingan, dan sebuah lagi 
dari rijang. Tingkat patinasi dan pembundaran artefak yang diperoleh pada TP1 seperti terlihat dalam tabel 2 berikut.

Tabel 2.

\begin{tabular}{|l|c|c|c|c|}
\hline \multicolumn{1}{|c|}{ Kondisi } & Tingkat awal & Tingkat sedang & Tingkat lanjut & Jumlah \\
\hline Patinasi & - & 12 & - & 12 \\
\hline Pembundaran & 1 & 10 & 1 & 12 \\
\hline
\end{tabular}

\section{c. Teras 3}

Pada lokasi teras 3 diwakili oleh TP5. Pada TP5 ini ditemukan 7 buah artefak paleolitik yang terdiri dari 2 serpih, 2 serut, sebuah batu dipangkas, sebuah fragmen alat, dan sebuah serpihan/limbah. Bahan artefak terdiri dari tufa kersikan (4 artefak), kalsedon ( 2 artefak), dan sedimen kersikan. Adapun tingkat patinasi dan pembundaran pada artefak dapat dilihat dalam tabel 3.

Tabel 3.

\begin{tabular}{|l|c|c|c|c|}
\hline \multicolumn{1}{|c|}{ Kondisi } & Tingkat awal & Tingkat sedang & Tingkat lanjut & Jumlah \\
\hline Patinasi & 2 & 5 & 0 & 7 \\
\hline Pembundaran & 4 & 3 & 0 & 7 \\
\hline
\end{tabular}

\section{d. Teras 4}

Pada teras 4 yang diwakili oleh TP2 ditemukan 5 artefak paleolitik yang terdiri dari 2 serpih, 2 serut, dan sebuah batu inti. Empat artefak diantaranya dibuat dari bahan gamping kersikan, dan sebuah dari bahan lempung kersikan. Tingkat patinasi dan pembundaran artefak paleolitik yang ditemukan pada TP2 seperti dalam tabel 4 berikut.

Tabel 4 .

\begin{tabular}{|l|c|c|c|c|}
\hline \multicolumn{1}{|c|}{ Kondisi } & Tingkat awal & Tingkat sedang & Tingkat lanjut & Jumlah \\
\hline Patinasi & 3 & 2 & - & 5 \\
\hline Pembundaran & 5 & - & - & 5 \\
\hline
\end{tabular}

\section{Informasi Hasil Analisis}

Berdasarkan hasil klasifikasi terhadap tingkat patinasi dan pembundaran artefak diketahui bahwa kondisi artefak dalam satu lokasi (TP/SP) berbeda. Hal ini menunjukkan bahwa sekumpulan artefak yang terendapkan pada lokasi tersebut berasal dari berbagai lokasi, baik dalam satuan waktu maupun jarak. 
Dari tabel 1 dapat kita ketahui bahwa 4 alat paleolitik yang terendapkan pada SP1 semuanya telah mengalami patinasi tingkat lanjut. Hal tersebut menunjukkan bahwa artefak paleolitik yang berada pada SP1 semuanya dari masa yang sama, yaitu dari masa yang tertua. Usia artefak pada SP1 ini dapat diperkirakan paling tidak semasa dengan usia pembentukan teras tempat pengendapannya, yaitu teras 1. Sementara berdasarkan dari tingkat pembundaran artefak dapat diketahui bahwa artefak yang diendapkan pada SP1 berasal dari berbagai tempat dalam jarak yang berbeda. Dapat ditarik gambaran bahwa sekumpulan artefak pada SP1 tersebut berasal dari lingkungan sekitarnya ( 1 artefak), dari tempat yang cukup jauh ( 2 artefak), maupun dari tempat yang jauh (1 artefak).

Hasil klasifikasi seperti dalam tabel 2 menunjukkan bahwa kondisi 12 artefak alat paleolitik yang diendapkan pada TP1 semuanya telah mengalami patinasi dalam tingkat sedang. Namun tingkat pembundaran artefaknya berbeda-beda, pembundaran sebuah artefak baru dalam taraf tingkat awal, 10 artefak dalam taraf tingkat lanjut, dan sebuah lagi dalam tingkat lanjut. Hal itu memberikan arti bahwa semua artefak pada TP1 berasal dari masa yang sama. Dapat diperkirakan usia artefak paling tidak semasa dengan pembentukan teras 2, tempat pengendapan artefak tersebut. Sebagian besar artefak dari TP1 ini berasal dari tempat yang cukup jauh dari lokasi pengendapan terakhir (teras 2 di TP1), dan sebagian kecil berasal dari lingkungan sekitarnya serta dari tempat yang lebih jauh lagi.

Kondisi 7 artefak paleolitik pada TP5 seperti terlihat dalam tabel 3, menunjukkan adanya perbedaan dalam tingkat patinasi maupun pembundaran. Tingkat patinasi pada 2 artefak baru dalam taraf awal, dan 5 artefak diantaranya dalam taraf sedang. Sementara tingkat pembundaran pada 4 artefak tersebut baru dalam taraf awal, sedangkan pada 3 artefak lainnya dalam taraf sedang. Kondisi artefak pada TP5 ini memberikan pengertian bahwa 7 artefak yang terendapkan pada TP5 berasal dari masa yang berbeda, 2 artefak dari masa yang lebih muda sedang 5 artefak lainnya berasal dari masa yang lebih tua. Dapat diduga 2 artefak yang berumur lebih muda pada TP5 tersebut paling tidak seumur dengan teras pada TP5 (teras 3), sedangkan 5 artefak lainnya berasal dari masa yang lebih tua yaitu dari rombakan teras di atasnya (teras 2 ) yang terendapkan lagi pada teras tersebut. Sementara perbedaan pada tingkat pembundaran pada artefak TP5 menunjukkan bahwa sekumpulan artefak yang diendapkan pada teras di TP5 ini, 4 artefak diantaranya berasal dari lingkungan sekitar lokasi TP5 dan 3 artefak lainnya berasal dari tempat cukup jauh jaraknya sebelum terendapkan pada teras 3 di TP5 tersebut.

Sementara itu hasil klasifikasi kondisi 5 artefak dari TP2 menunjukkan bahwa terdapat perbedaan dalam tingkat patinasi. Tingkat patinasi pada 3 artefak baru dalam tingkat awal dan 2 artefak lainnya dalam tingkat sedang. Hal ini memberikan petunjuk mengenai adanya 2 kelompok artefak yang berasal dari masa yang berbeda. 
Kelompok pertama yang terdiri dari 3 artefak menunjukkan dari masa yang lebih muda dari pada kelompok kedua yang terdiri dari 2 artefak.

Tingkat patinasi artefak di TP2 pada teras 4 ini sama dengan tingkat patinasi pada artefak yang ditemukan di TP5 yang terletak pada teras di atasnya, yaitu teras 3 . Oleh karena itu dapat diduga bahwa artefak kelompok pertama pada TP 2 berasal dari rombakan endapan teras di atasnya (teras 3 ), dan artefak kelompok kedua berasal dari rombakan endapan teras yang lebih tua lagi dari pada teras di TP5, kemungkinan dari teras 2. Sementara tingkat pembundaran artefak dari TP2 menunjukkan kesamaan, yaitu semuanya dalam tingkat awal. Hal ini memberikan arti bahwa semua artefak tersebut berasal dari lingkungan TP2, tidak berasal dari tempat yang jauh sebelum diendapkan terakhir kalinya pada teras di TP2.

Berdasarkan hasil analisis kondisi artefak pada TP2 tersebut dapat diketahui bahwa semua artefak yang terendapkan pada teras 4 yang merupakan teras terbawah tersebut berasal dari artefak yang telah terendapkan pada teras-teras di atasnya yang telah terombak. Hal ini berarti tidak ada artefak yang merupakan Budaya Pacitanian yang semasa dengan pembentukan teras 4 yang merupakan teras terendah.

Apabila kita kembalikan ke posisinya, kondisi artefak khususnya tingkat patinasi artefak yang diperoleh pada SP1, TP1, TP2, dan TP5 tersebut ternyata berkorelasi dengan ketinggian/elevasi lokasi. Patinasi tingkat awal hanya ditemukan pada lokasi yang rendah, yaitu pada TP2 dan TP5 yang berketinggian antara $2 \mathrm{~m}$ hingga $6 \mathrm{~m}$ dari dasar Sungai Baksoka. Patinasi tingkat menengah hanya dijumpai pada artefak yang dtemukan pada lokasi dengan ketinggian menengah ke bawah, yaitu pada TP1, TP5, dan TP2 yang berketinggian $2 \mathrm{~m}$ hingga $14 \mathrm{~m}$ dari dasar Sungai Baksoka. Sementara patinasi tingkat lanjut hanya menempel pada artefak yang ditemukan pada lokasi tertinggi, yaitu pada SP1 yang berketinggian $17 \mathrm{~m}$ dari dasar Sungai Baksoka.

Adanya korelasi antara tingkat patinasi artefak dengan ketinggian lokasi tersebut mendukung adanya beberapa teras sungai yang mempunyai tingkatan umur berbeda. Artefak dengan patinasi tingkat lanjut merupakan artefak dari teras (pengandung budaya) tertua. Artefak dengan patinasi tingkat sedang merupakan artefak dari teras menengah. Sementara artefak dengan patinasi tingkat awal merupakan artefak dari teras bawah. Keberadaan artefak dengan patinasi tingkat sedang yang bercampur dengan artefak dengan patinasi tingkat awal di teras bawah karena telah terombak/lepasnya artefak yang berpatinasi tingkat sedang tersebut pada matriksnya dan tertranportasi ke bawah. 


\section{Penutup}

Penerapan analisis kondisi artefak yang meliputi tingkat patinasi dan pembundaran yang telah diterapkan pada sekumpulan artefak dari lembah Sungai Baksoka telah terbukti banyak membantu dalam penelitian. Hasil analisis ini sangat membantu dalam mendapatkan gambaran lokasi asal/awal dari sekumpulan artefak yang tercampur dalam pengendapannya. Dari hasil analisis ini pula dapat diketahui terasteras mana saja yang mengandung artefak, dan akhirnya didapat pula perkiraan kronologi artefak tersebut.

Namun demikian dalam penerapan analisis ini terdapat kendala, yaitu pengaruh subyektivitas dalam mengklasifikasi/menentukan tingkatan patinasi dan pembundaran suatu artefak, yang akhirnya akan sangat berpengaruh pula terhadap hasilnya. Selain itu dalam pembagian tingkatan kondisi (patinasi dan pembundaran) dalam kelompokkelompok yang kurang rinci dapat mengaburkan keadaan yang sebenarnya. Hal ini terlihat dalam pembagian kelompok tingkatan kondisi artefak yang dipakai dalam analisis artefak dari lembah Sungai Baksoka. Klasifikasi tingkatan kondisi yang kurang rinci (dalam 3 kelompok), yaitu tingkat awal, tingkat sedang, dan tingkat lanjut yang dipakai dalam analisis ini dapat kurang meyakinkan hasilnya. Sebagai contoh dalam kasus analisis tingkat patinasi artefak dari TP2. Adanya kesamaan dalam pengelompokan tingkat patinasi artefak dari TP2 dengan TP5 menghasilkan informasi bahwa pada TP2 tersebut tidak ada artefak yang semasa dengan usia teras tersebut. Semua artefak yang terendap pada teras 4 di lokasi TP2 berasal dari artefak yang berada di teras-teras atasnya. Hasil analisis ini ada kemungkinan salah, boleh jadi sebenarnya terdapat pula artefak pada TP2 tersebut yang seusia dengan pembentukan teras 4 .

Berkaitan dengan hal ini maka dalam penerapan analisis tingkat patinasi dan pembundaran artefak apabila dilakukan secara kuantitatif hasilnya akan lebih obyektif. Demikian pula mengenai pengklasifikasian tingkatan patinasi dan pembundaran, sebaiknya dikelompokkan dalam kelompok-kelompok yang lebih rinci. 


\section{KEPUSTAKAAN}

Bartstra, Gert-Jan. 1976. "Contributions to the Study of the Palaeolithic Patjitan Culture Java, Indonesia", Part 1, dalam Studies in South Asian Culture, Vol. VI. Leiden: E.J. Brill.

Bemmelen, R.W. van. 1949. The Geology of Indonesia vol. I A. General Geology. The Hague: Martinus Nijhoff.

Heekeren, HR van. 1972. "The Stone Age of Indonesia", VKI 61. The Hague-Martinus Nijhoff.

Hidayat, Muhammad, dan Harry Widianto. 2000. Laporan Penelitian Arkeologi Kronologi dan Pendukung Budaya Pacitanian Tahap I. Belum terbit.

, Harry Widianto, Budianto Toha, Nurhadi Rangkuti., 2001. Laporan Penelitian Arkeologi Kronologi dan Pendukung Budaya Pacitanian Tahap II. Belum terbit.

Sartono, S, dkk. 1978. "Undak Sungai Baksoka Berdasarkan Analisa Foto Udara", Berita Penelitian Arkeologi No. 19. Jakarta: Proyek Penelitian dan Penggalian Purbakala Departemen P \& K. 